\title{
Biomass loss and nutrient redistribution in an Indonesian Thalassia hemprichii seagrass bed following seasonal low tide exposure during daylight
}

\author{
Johan Stapel ${ }^{1, *}$, Rahel Manuntun ${ }^{2}$, Marten A. Hemminga ${ }^{1}$ \\ ${ }^{1}$ Netherlands Institute of Ecology, Centre for Estuarine and Coastal Ecology, Vierstraat 28, 4401 EA Yerseke, \\ The Netherlands \\ ${ }^{2}$ Bugenesia Programme, PO Box 1624, Ujung Pandang 90016, Indonesia
}

\begin{abstract}
The intertidal reef flat of Barang Lompo Island, Indonesia, is exposed to air for several hours per day on the days around spring tides. The time of exposure shows a seasonal pattern. In the period January-June, the reef flat only runs dry at night, whereas in the period July-December, exposure only occurs during daylight. During the low tide daylight exposure period of July-December 1993, the leaf and rhizome biomasses $\left(\mathrm{g} \mathrm{m}^{-2}\right)$ declined significantly by 61 and $37 \%$, respectively. Total rhizome length remained unchanged. C-and P-concentrations (\% of dry weight) of leaves showed no change, while the leaf $\mathrm{N}$-concentration increased by $25 \%$. C-, N-and P-contents of leaves showed a decline that was strongly correlated to leaf biomass decline. In the rhizomes, C-concentration declined by $8 \%$, but the $\mathrm{N}$ - and $\mathrm{P}$-concentrations increased by 111 and $25 \%$, respectively. Rhizome C-content $\left(\mathrm{g} \mathrm{m}^{-2}\right)$ declined $(43 \%), \mathrm{N}$-content increased $(46 \%)$ and P-content did not change. Total $\mathrm{C}$ - and $\mathrm{P}$ contents of the summed biomass of leaves and rhizomes declined by 46 and $34 \%$, respectively, but $N$. content showed no change. Ammonium and phosphate concentrations in the water column and pore water phosphate were not significantly different during daylight exposure compared to during nocturnal exposure. Ammonium concentration in the pore water, however, was 1.6 times higher during daylight exposure. Results show that during a period of frequent daylight exposure, the nutrient status in the intertidal Thalassia hemprichii seagrass bed changed considerably. Despite biomass reduction, the total nitrogen content in leaves and rhizomes together was constant, which was achieved by an enhanced nitrogen accumulation in the rhizomes. Two theories possibly responsible for the stable sum of the total leaf and rhizome nitrogen content are discussed. The first theory describes the seagrass bed as a relatively closed system with respect to nutrient cycles: detached leaf fragments remain trapped within the meadow. The second theory postulates that the loss of part of the photosynthesising canopy due to daylight exposure has a series of consequences for microbial $\mathrm{N}$-transformation processes in the sediment, which indirectly affects the plants nitrogen status. This study shows that Thalassia hemprichii, covering the reef flat of an intertidal tropical offshore coral island, which is often considered as a nutrient-poor environment, is rather resilient to a significant canopy die-off and concomitant nutrient losses.
\end{abstract}

KEY WORDS: Daylight exposure - Seagrass - Biomass redistribution - Nutrient contents - Thalassia hemprichii Indonesia

\section{INTRODUCTION}

Seagrass beds occur in shallow coastal areas around the world (Den Hartog 1970). Biomass and productivity

·E-mail: stapel@cemo.nioo.knaw.nl of seagrasses exhibit seasonal variation, which has been attributed to periodical fluctuations of environmental factors such as light, nutrient availability, temperature, salinity, herbivory and hydrological conditions (e.g. Pérez \& Romero 1992, Baldwin \& Lovvorn 1994, Erftemeijer \& Herman 1994, Alcoverro et al. 1995, De Iongh et al. 1995, Philippart 1995). 
The comparatively uniform temperature and daylength in tropical areas allow rather constant seagrass biomass and growth throughout the year compared to temperate regions (Duarte 1989). Tidal exposure, however, may be responsible for seasonal variability in the structure and functioning of (tropical) shallow-water seagrass beds (Bulthuis \& Woelkering 1983, Brouns \& Heijs 1986, Erftemeijer \& Herman 1994). Tidal exposure of seagrass covered shallow reef flats and coastal areas in Indonesia often shows a seasonal pattern. During a period of several successive months each year, spring low tides, which cause these shallow areas to run dry, only occur during daylight, whereas spring tidal exposure during the rest of the year only occurs at night (Brouns \& Heijs 1986, Erftemeijer \& Herman 1994, De Iongh et al. 1995). Erftemeijer \& Herman (1994) showed that in South Sulawesi tidal daylight exposure in the period July 1991 -January 1992 caused an 80 to $90 \%$ reduction of the above-ground biomass of Thalassia hemprichii and Enhalus acoroides and a significant change in the specific leaf growth rate and elementary composition of the seagrass tissue. Furthermore, De longh et al. (1995) reported a significant $43 \%$ decrease of above-ground biomass of a Halodule uninervis meadow in the Moluccas, East Indonesia, between May and August 1991, coinciding with a similar shift of nocturnal spring low water to daylight spring low water. This massive, seasonal decline in aboveground seagrass biomass may have considerable consequences for the nutrient dynamics of these systems. Mobilisation of energy (carbohydrates) and nutrients stored in seagrass rhizomes allows regrowth of the lost seagrass canopy (e.g by herbivory; Greenway 1974, Dawes \& Lawrence 1979, 1980, Dawes et al. 1979. Tomasko \& Dawes 1989,1990 ). It is, however, not clear how these nutrient reserves are replenished in seagrass beds covering the intertidal reef flats of offshore coral islands. These environments are characterised by very clear, nutrient-poor waters, without an evident nutrient source (Erftemeijer 1994, Stapel et al. 1996a). Repeated significant loss of canopy biomass and concomitant nutrients due to leaf detachment caused by desiccation and burning could result in the perishing of seagrasses from these habitats. The long term persistence of these meadows, however, implies that a significant nutrient loss apparently does not occur.

In this study we examine the seagrass Thalassia hemprichii (Ehrenb.) Aschers. covering an intertidal reef flat of an offshore coral island in Indonesia. This is the same research location at which Erftemeijer \& Herman (1994) found clear evidence (using canonical correlation analysis) that daylight emergence caused significant changes in biomass and nutrient concentrations in seagrass leaves and rhizomes. The biomass and nutrient concentrations of the leaves and rhi- zomes were monitored during a 6 mo period of spring tidal daylight exposure and a subsequent period of 4 mo in which tidal exposure occurred at night only. The aims were (1) to quantify biomass loss during the period in which daylight exposure occurs and (2) to examine the distribution of nutrients among rhizomes, leaves, pore water and the water column during this period.

\section{MATERIALS AND METHODS}

Study area. The study was executed in a seagrass bed at the reef flat of Barang Lompo Island, located approximately $14 \mathrm{~km}$ off the coast in the Spermonde Archipelago. This archipelago, along the west coast of South Sulawesi, Indonesia, consists of a large group of coral islands and submerged reefs scattered on the Spermonde continental shelf (De Klerk 1982; Fig. 1). The reef flats of most of the islands and the shallow

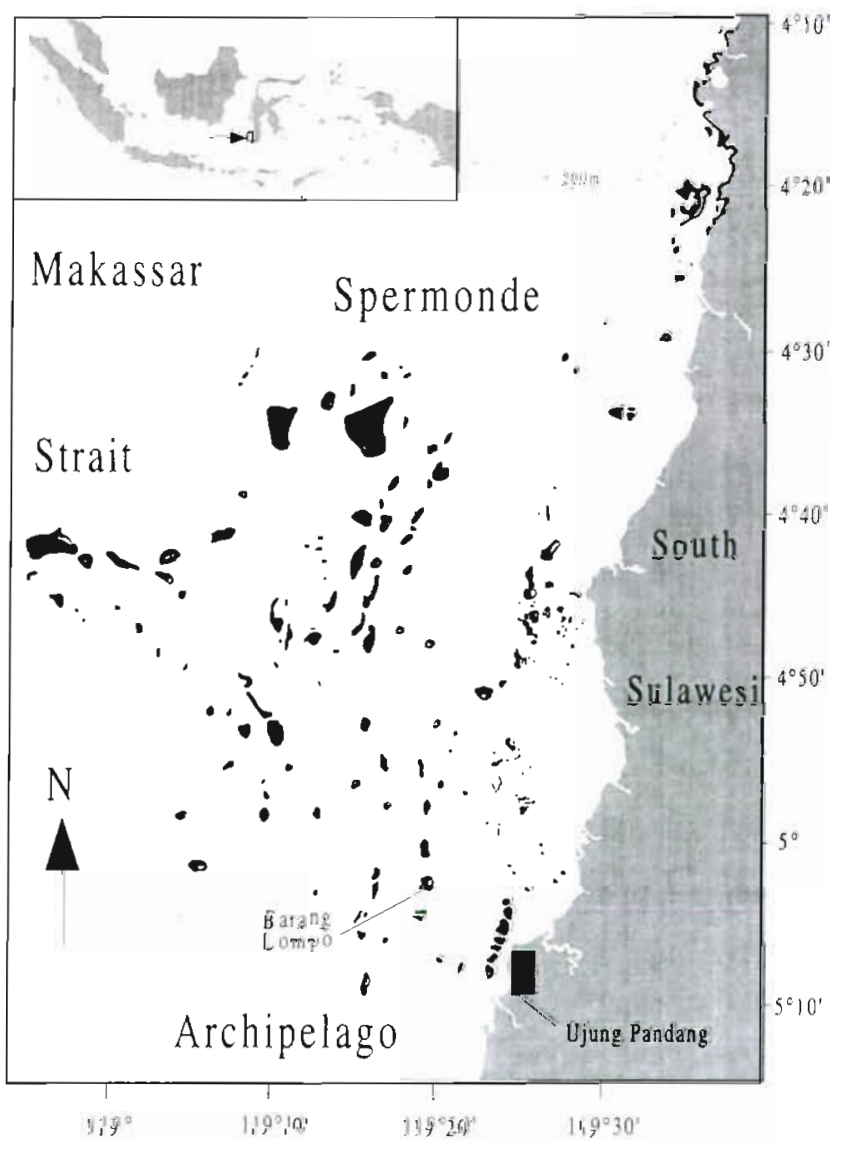

Fig. 1. Study area, showing islands and submerged reefs of the Spermonde Archipelago along the west coast of South Sulawesi, Indonesia (islands and mainland: grey submerged $^{2}$ reefs: black). Dashed lane: shelf edge (200 $\mathrm{m}$ depth). Inset: Indonesian Archipelago 


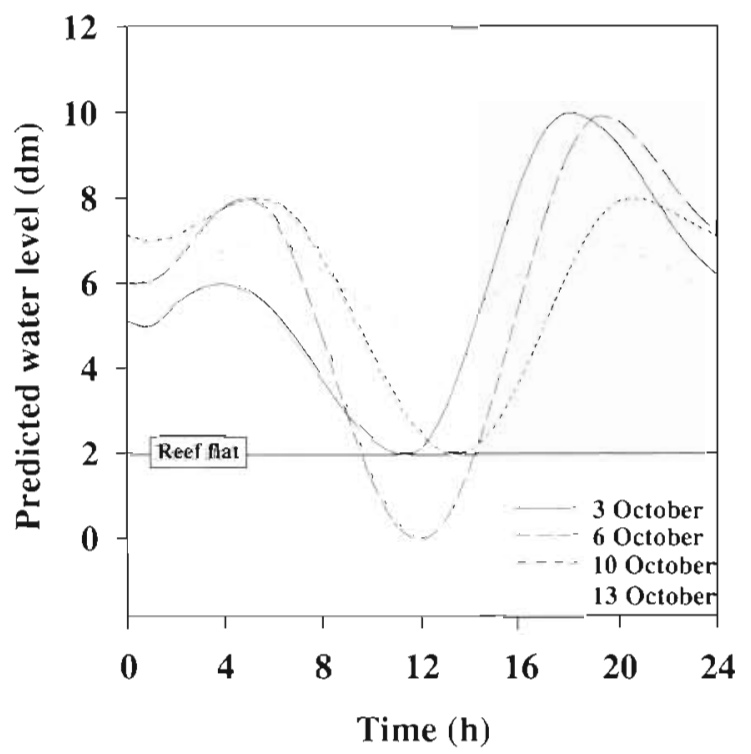

Fig. 2. Predicted tidal oscillation curves for the harbour of Ujung Pandang with respect to extreme low water (ELW; source: Dinas Hidro-Oseanologi TNI-AL, Jakarta, Indonesia) at the start of a daylight exposure period around spring tide ( 3 October), at spring tide (6 October), at the last day of a daylight exposure period (10 October) and at neap tide (13 October). The horizontal line indicates the level of the research location ( $2 \mathrm{dm}$ above ELW). On 3 and 10 October, the water level briefly drops to the reef flat surface; on 6 October, the seagrass bed is exposed to air for a period of $4 \mathrm{~h}$ around noon; between 10 and 13 October, the reef flat does not run dry at all

areas along the coast are covered with seagrass beds (Erftemeijer et al. 1993). The selected location is a coral island surrounded by a large intertidal reef flat with an extensive seagrass vegetation. The reef flat consists of coarse carbonate sand and coral rubble (93 to 100\% $\mathrm{CaCO}_{3 i}$ Erftemeijer 1994). The research was executed in the southwestern part of the reef flat. The seagrass bed on this part of the reef flat is dominated by Thalassia hemprichii; patches of Enhalus acoroides also occur. The location is situated $19 \pm 10 \mathrm{~cm}$ above extreme low water (ELW) (Erftemeijer \& Herman 1994). The seagrass bed at this location is exposed to air on the days around each spring low water. Fig 2 shows an example of the predicted water levels for 4 days in October 1993. Exposure of the seagrass bed starts on 3 October with a brief exposure period $3 \mathrm{~d}$ before the actual occurrence of spring low water. On each day that follows, the period of exposure progressively lasts longer, up to a maximum of $4 \mathrm{~h}$ on the day of spring low water ( 6 October). During the next $4 \mathrm{~d}$, the exposure period becomes shorter. After 10 October, the seagrass bed does not run dry until the next period of ca $9 \mathrm{~d}$ around spring low water. In the period July-December 1993, spring low water only occurs during daylight
(Fig 3). Exposure of the seagrass bed during daylight co-occurs with intense insolation, high water temperatures of (small) tidal pools, severe desiccation and 'burning' of the seagrass leaves (Erftemeijer \& Herman 1994). Due to the absence of the deleterious effects of insolation during nocturnal exposure, the seagrass bed may recover during the other 6 mo period. We counted a total of 110 days with daylight exposure of the seagrass bed (up to $6 \mathrm{~h} \mathrm{~d}^{-1}$ ). These days were grouped in 16 periods of 1 to 9 successive days around the spring tides. The number of successive days per period and the duration of daylight exposure per day increased gradually from July to October, while the time of exposure shifted from the afternoon (July-August) to noon (September-October). Thereafter, duration of exposure and the number of days per period declined and shifted to morning hours (November-December).

Seagrass parameters. Three replicate plugs $(25 \times$ $25 \mathrm{~cm}$ ) of Thalassia hemprichij were harvested on each sampling occasion. From 3 June to 26 July 1993 and from 1 January to 25 April 1994, 1 sample was taken every 4 wk. From 26 July 1993 to 1 January 1994, samples were taken on the days just before and after a period of daylight exposure around a spring tide. After 1 January 1994, samples were taken in order to detect recovery during a period in which only nocturnal exposure occurs (Fig. 3). Samples were divided into leaves and rhizomes (including vertical rhizomes) and the number of shoots was counted. Roots were discarded because accurate sediment-free sampling of these organs for determination of biomass and nutrient concentration appeared very difficult. Furthermore, results from Erftemeijer \& Herman (1994) suggest that roots were not significantly affected by daylight exposure. The sheaths (remains of old leaves still attached to the plant) were considered as parts that do not belong to

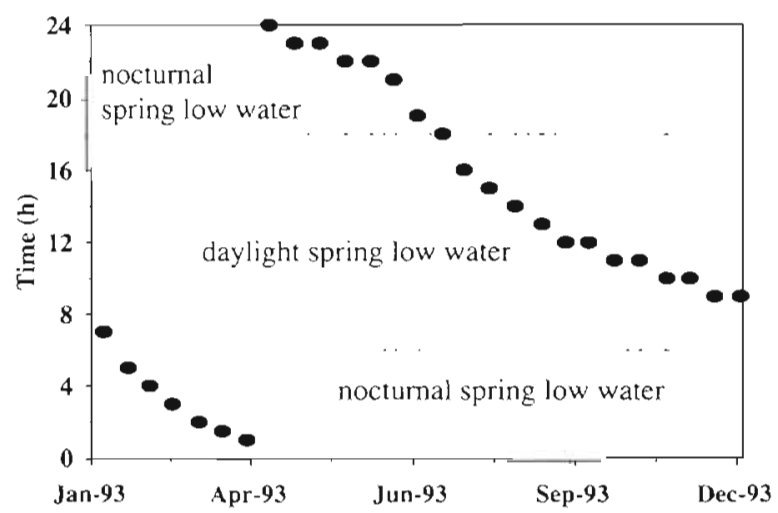

Fig. 3. Predicted time and date of occurrence of each spring low water in 1993 for the harbour of Ujung Pandang (source: Dinas Hidro-Oseanologi TNI-AL, Jakarta). The area between the horizontal dashed lines represents the daylight period 106:00 to $18: 00 \mathrm{~h}$ ) 
the living seagrass canopy and were therefore discarded as well. Sediment was removed and epiphytes were gently wiped off. The samples were dried to constant dry weight at $80^{\circ} \mathrm{C}$. Thereafter, the total length of the rhizomes in each sample was measured. Tissue $\mathrm{C}$ and $\mathrm{N}$-concentrations were determined using a Carlo Erba NA $1500 \mathrm{CN}$ analyser. P was analysed colorimetri- cally (Allen 1974) after strong acid microwave destruction according to Nieuwenhuize et al. (1991).

Inorganic nutrients. Nutrient samples (ammonium and phosphate) of the water column and pore water were taken bimonthly (May-September) or 4 times per month (October-December). The water column was sampled in $1 \mathrm{l}$ opaque bottles and transported on ice. Af-
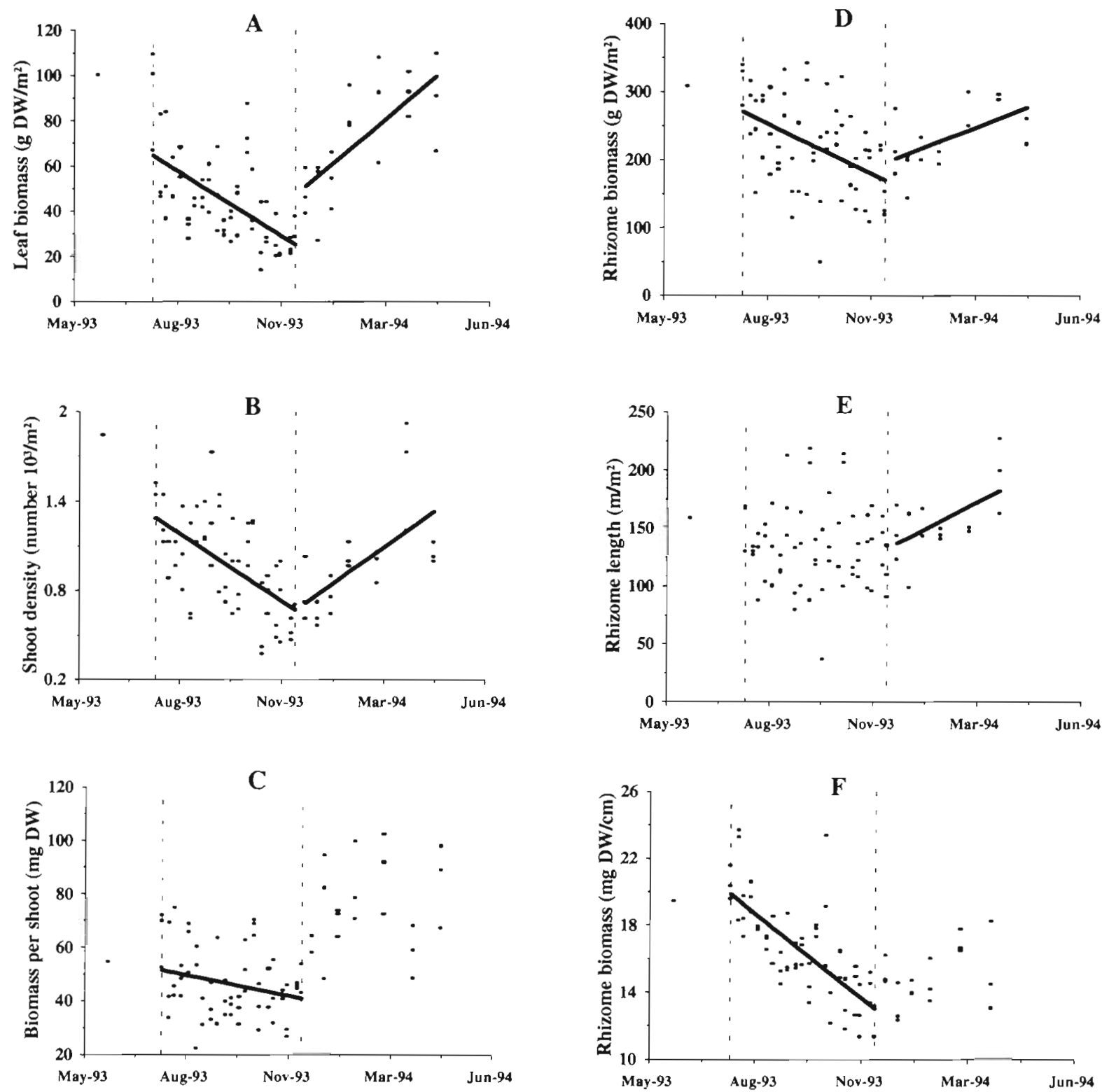

Fig. 4. Thalassia hemprichu. Changes in biological variables of leaves, shoots and rhizomes in response to daylight emergence. Solid lines indicate linear fits of the type $y=a x+b$ for the data collected between 26 July and 20 December 1993 (data in between vertical dashed lines), and $y=c x+d$ for the data collected in the recovery period ( 1 January to 25 April), for $x$ (date) $=1$ on 1 January 1993. (A) Leaf biomass $\left(a=-0.287\right.$ and $b=124, R^{2}=0.363, p<0.01 ; c=0.385$ and $\left.d=-85.2, R^{2}=0.491, p<0.01\right) ;(B)$ shoot density $\left(a=-4.54 \times 10^{-3}\right.$ and $b=2.23, \mathrm{R}^{2}=0.373, \mathrm{p}<0.01 ; c=4.89 \times 10^{-3}$ and $\left.d=-1.02, \mathrm{R}^{2}=0.406, \mathrm{p}<0.01\right)$; $(\mathrm{C})$ shoot biomass $\left(a=-76.4 \times 10^{-3} \text { and } b=67.2, R^{2}=0.065, \mathrm{p}<0.05\right)_{;}$(D) rhizome biomass $\left(a=-0.738\right.$ and $b=424, R^{2}=0.213, p<0.01 ; c=0.593$ and $\left.d=-8.47 ; R^{2}=0.353, p<0.01\right)_{;}$(E) rhizome length $\left(c=0.463 \text { and } d=-27.6 \times 10^{3}, R^{2}=0.351, p<0.05\right)_{i}$ and (F) rhizome biomass $\left(a=-50.2 \times 10^{-3}\right.$ and $\left.b=30.3, R^{2}=0.545, p<0.01\right)$. Note that Rhizome biomass in (D) is expressed in $\mathrm{g} \mathrm{DW} \mathrm{m}^{-2}, w h i l e$ in $(F)$ it is expressed in $\mathrm{mg} \mathrm{DW} \mathrm{cm}^{-1}$ rhizome 
ter filtration (Whatman GF/C), the dissolved inorganic ammonium and phosphate contents of the samples were determined colorimetrically according to Strickland \& Parsons (1972), using a Nanocolor $100 \mathrm{D}-\mathrm{MN}$ filter photometer. Sediment samples were taken with small hand corers (diameter $6 \mathrm{~cm}$ ) to a depth of $12 \mathrm{~cm}$. Each core was separated into $2 \mathrm{~cm}$ sections. The corresponding sections of 6 successive cores were combined and treated as 1 sample. Two series of 6 cores were collected at each sampling occasion, representing 2 replicates. These samples were transported in sealed plastic bags on ice for further treatment in the laboratory. Within $6 \mathrm{~h}$ of sampling, plant parts, shells and large rubble were removed and pore water was subsequently extracted by filtration over membrane filters $(0.45 \mu \mathrm{m}$; Schleicher \& Schüll GmbH, Dassel, Germany) under a maximum of 1 atm effective pressure using nitrogen gas (Kelderman 1985). Subsequently, the dissolved inorganic ammonium and phosphate in the pore water were analysed.

Data analysis. The change of the measured seagrass parameters as a function of time was tested using linear regression. To allow the use of linear regression, data were divided into 2 periods. The effect of tidal daylight exposure was tested for using data collected between $26 \mathrm{July}$ and 20 December A possible recovery of the measured parameters after the season of tidal daylight exposure ended was tested for data collected after 20 December (recovery period)

To detect a difference in nutrient concentrations between the periods of nocturnal and daylight exposure, the nutrient data were divided into 2 groups: samples taken in the period May-July 1993 and samples taken in the period August-December 1993. Differences in the pore water ammonium and phosphate concentrations were tested using 1-way ANOVA. For the ammonium and phosphate concentrations in the water column, averages \pm SD were calculated.

\section{RESUL.TS}

\section{Daylight exposure}

Both the leaf and the rhizome biomasses ( $g$ DW $\mathrm{m}^{-2}$ ) declined significantly in the daylight exposure period (26 July to 20 December; Fig. 4A, D; $p<0.01$ ). The reduction in leaf biomass was approximately $61 \%$, while rhizome biomass declined by $37 \%$. The decline in leaf biomass was due to a combination of a decline in shoot density $(48 \%$; Fig. $4 \mathrm{~B} ; \mathrm{p}<0.01)$ and a decline in biomass per shoot $\left(20 \%\right.$; Fig $\left.4 \mathrm{C}_{i} \mathrm{p}<0.05\right)$.

Total rhizome length $\left(\mathrm{m} \mathrm{m}^{-2}\right)$ in each sample showed considerable variation and did not significantly change over time (Fig. 4E; $p>0.05$ ). The decline of rhizome biomass in the daylight exposure period was therefore due to a decline in its dry weight per unit of length (Fig. 4F; $\mathrm{p}<0.01$ ).

C- and P-concentrations ( $\%$ of dry weight) in the leaves showed no significant change during the daylight exposure period (Fig. 5A, C; p >0.05), but the Nconcentration increased by $25 \%$ (Fig. $5 \mathrm{~B}$; p $<0.01$ ). The total $\mathrm{C}$-, $\mathrm{N}$ - and P-contents of the leaves $\left(\mathrm{g} \mathrm{m}^{-2}\right)$
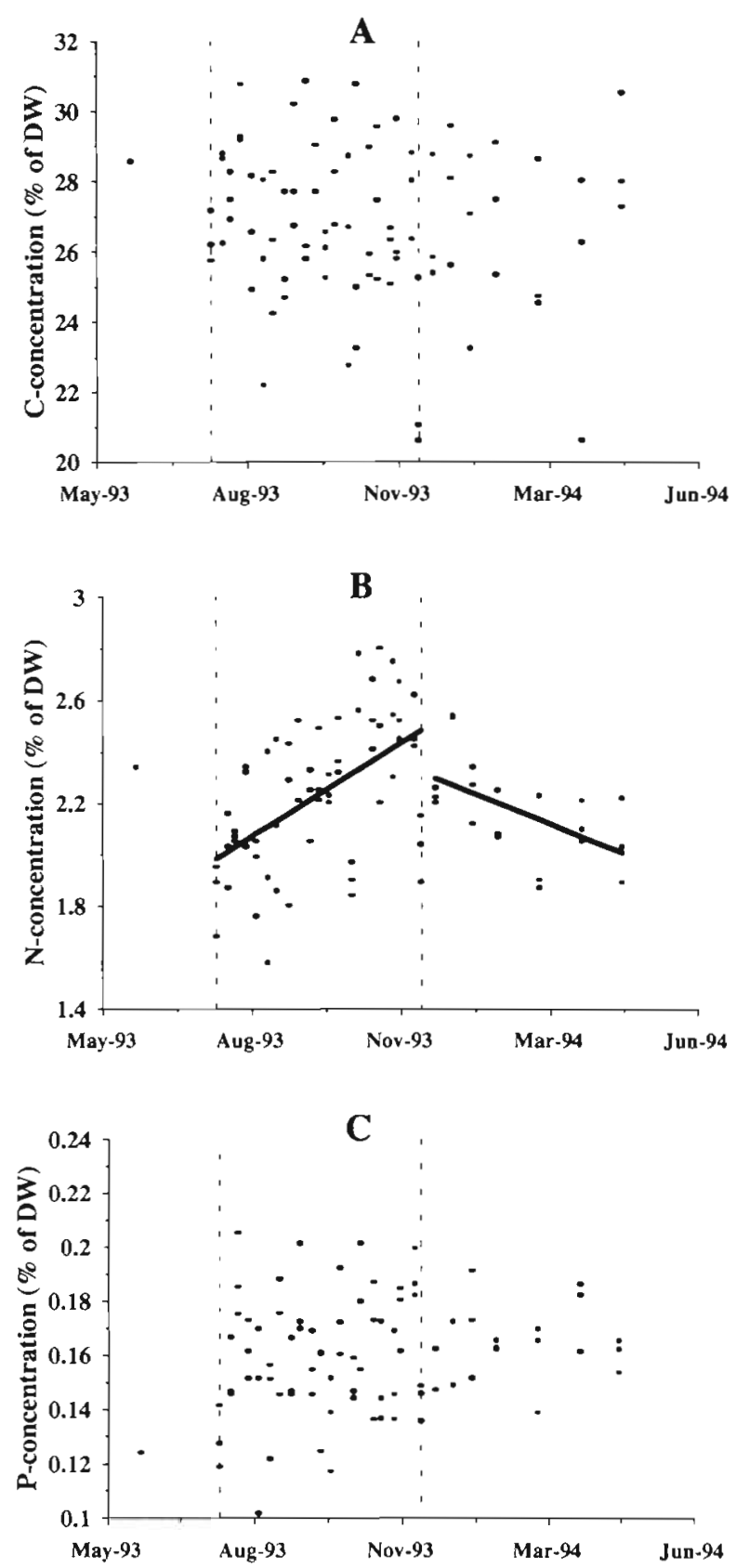

Fig. 5. Thalassia hemprichii. Changes in nutrient concentrations of leaves. Solid lines and associated constants defined as in legend of Fig. 4. (A) C-concentration; (B) N-concentration $l a=3.64 \times 10^{-3}$ and $b=1.23, \mathrm{R}^{2}=0.295, \mathrm{p}<0.01 ; c=-2.30 \times$ $10^{-3}$ and $d=3.11, R^{2}=0.276, p<0.05$ ); (C) P-concentration 
declined significantly by 63,49 and $56 \%$, respectively, and showed a strong correlation, leaf biomass decline (Pearson's correlation coefficient of $0.986,0.957$ and 0.927, respectively; $\mathrm{p}<0.01$ )

In the rhizomes, the $\mathrm{C}$-concentration declined by $8 \%$ during the daylight exposure period (Fig. 6 $\mathrm{A}_{i} \mathrm{p}<0.01$ ), but the $\mathrm{N}$ - and $\mathrm{P}$-concentrations increased by 111 and $25 \%$, respectively (Fig. 6B, C; p < 0.05). Total rhizome C- content $\left(\mathrm{g} \mathrm{m}^{-2}\right)$ declined $(43 \% ; \mathrm{p}<0.01)$, while that of $\mathrm{N}$ increased $(46 \% ; p<0.05)$ (Fig. 6D, E). Total P-content in the rhizomes did not show a significant change (Fig. 6F). The decline in rhizome C-content showed a strong correlation with the rhizome biomass reduction (Pearson's correlation coefficient, $0.993 ; \mathrm{p}<0.01$ ). Total decline in rhizome biomass was $0.74 \mathrm{~g} \mathrm{~m}^{-2} \mathrm{~d}^{-1}$ in the period $26 \mathrm{July}$ to 20 December (calculated from the corresponding re-
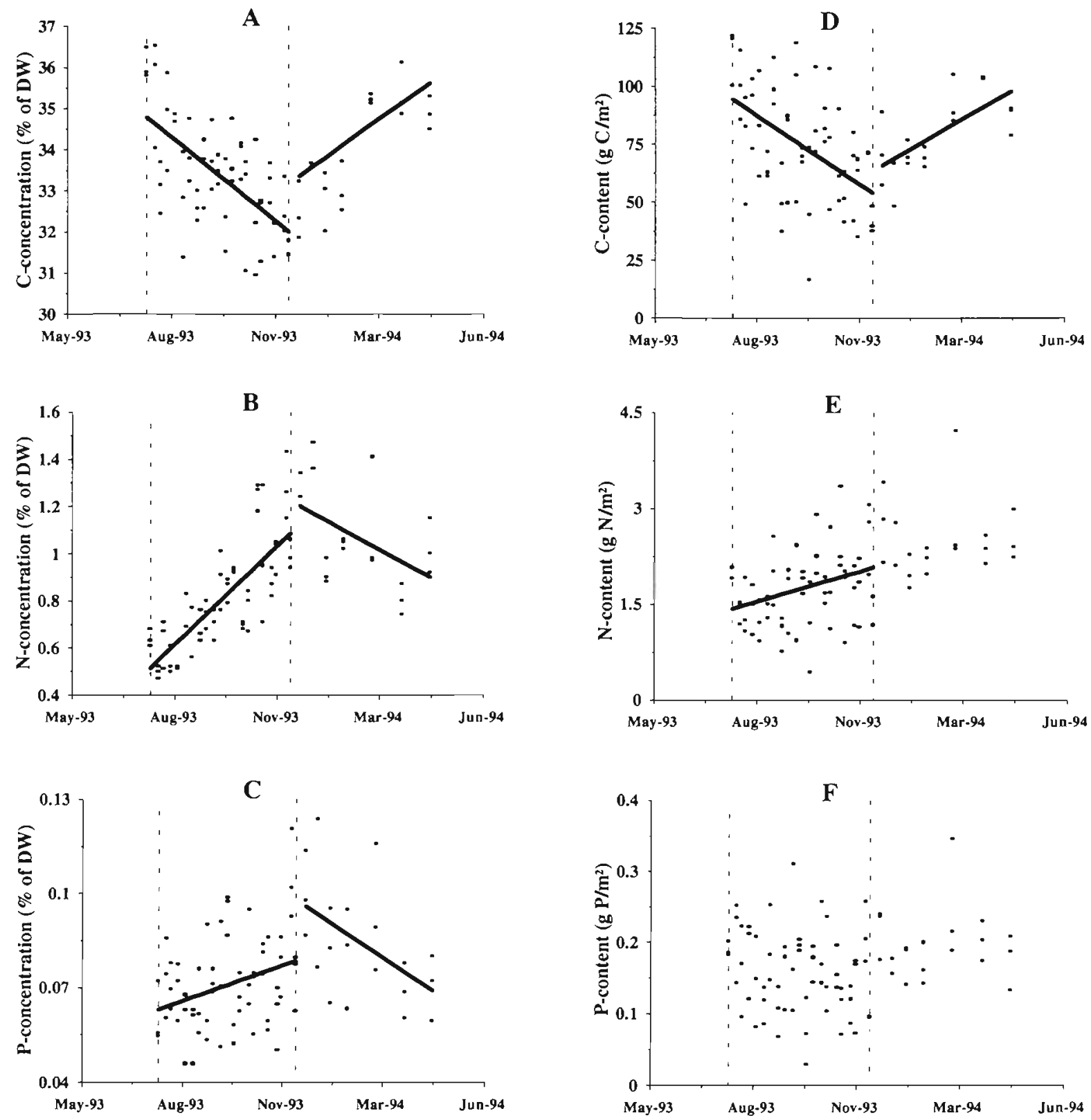

Fig. 6. Thalassia hemprichii. Changes in nutrient concentrations and contents of rhizomes. Solid lines and associated constants defined as in legend of Fig. 4. (A) C-concentration $\left(a=-20.3 \times 10^{-3}\right.$ and $b=39.0, \mathrm{R}^{2}=0.404, \mathrm{p}<0.01 ; c=22.6 \times 10^{-3}$ and $d=24.7$, $\left.\mathrm{R}^{2}=0.611, \mathrm{p}<0.01\right) ;(\mathrm{B}) \mathrm{N}$-concentration $\left(a=4.18 \times 10^{-3}\right.$ and $b=-0.351, \mathrm{R}^{2}=0.609, \mathrm{p}<0.01 ; c=-2.38 \times 10^{-3}$ and $d=2.04, \mathrm{R}^{2}=$ $0.215, \mathrm{p}<0.05) ;(C)$-concentration $\left(a=0.113 \times 10^{-3}\right.$ and $b=0.0397, R^{2}=0.101, p<0.05 ; c=0.211 \times 10^{-3}$ and $d=0.171, R^{2}=0.216$, $\mathrm{p}<0.05) ;(\mathrm{D}) \mathrm{C}$-content $\left(a=-0.295\right.$ and $b=155, \mathrm{R}^{2}=0.259, \mathrm{p}<0.01 ; c=0.254$ and $\left.d=-24.1, \mathrm{R}^{2}=0.437, \mathrm{p}<0.01\right) ;(E) \mathrm{N}$-content $\left(a=4.75 \times 10^{-3}\right.$ and $\left.b=0.441, R^{2}=0.090, p<0.05\right)$; and (F) P-content 
gression line in Fig. 4D). Rhizome C-content declined by $0.30 \mathrm{~g} \mathrm{~m}^{-2} \mathrm{~d}^{-1}$ during the same period (calculated from the corresponding regression line in Fig. 6D). If we assume that the decline in rhizome C-content is caused by carbohydrate $\left[\left(\mathrm{CH}_{2} \mathrm{O}\right)_{2}\right]$ mobilisation, the rhizome biomass would reduce by $30 / 12$ (ratio of $\mathrm{CH}_{2} \mathrm{O}: \mathrm{C}$ ) times the $\mathrm{C}$-content reduction: $30 / 12 \times 0.30 \mathrm{~g} \mathrm{~m}^{-2} \mathrm{~d}^{-1}=0.75 \mathrm{~g} \mathrm{~m}^{-2} \mathrm{~d}^{-1}$.

When the combined biomass of leaves and rhizomes was considered (Fig. 7A, B, C), the N-content did not significantly change during the daylight exposure period $(p>0.05)$, whereas that of $C$ and $P$ decreased ( 46 and $34 \%$, respectively; $\mathrm{p}<0.01$ ).

\section{Recovery}

In general, the seagrass parameters that changed during the period of daylight exposure returned approximately to their initial values in the period of nocturnal exposure that followed (Figs. 4 to 7 ). This suggests that, most likely, tidal exposure explains the observed seasonal patterns. However, in a few cases, the recovery period did not show the reverse pattern of the daylight exposure period. Rhizome length did not change during daylight exposure. In the recovery period, however, a significant increase was observed (Fig. 4E). On the other hand, the dry weight per unit of rhizome length declined during daylight exposure, but recovery was not significant (Fig. $4 \mathrm{~F}$ ). Also the rhizome $\mathrm{N}$-content increased during daylight exposure, but did not decline during the recovery period (Fig. 6E).

Furthermore, the way in which the data were statistically approached was not appropriate for all parameters. Linear regression of the data on the biomass per shoot did not reveal a significant increase in the recovery period after 20 December, although the decrease during the daylight exposure period had been significant. One-way ANOVA, however, revealed a significant ( $\mathrm{p}<0.01$ ) difference between the data on biomass per shoot observed during the daylight exposure period and those observed during the recovery period. It appeared that within a short period (ca $50 \mathrm{~d}$ ) after the end of the daylight exposure period, the biomass per shoot increased by $85 \%$. Also, linear regression did not reveal a significant change in the total $\mathrm{N}$ - and $\mathrm{P}$-contents during the recovery period (Fig. 7B, C), but 1 -way ANOVA showed a significant difference in the total $N$ and $\mathrm{P}$-contents between the data of the daylight exposure and the recovery period $(\mathrm{p}<0.01)$.

\section{Inorganic nutrients}

The ammonium and phosphate concentrations in the water column in the period May-July were $2.7 \pm 4.3$ (n
=6) and $0.11 \pm 0.07 \mu \mathrm{M}(\mathrm{n}=4)$, respectively. These concentrations were not significantly different from the ammonium and phosphate concentrations in the water column in the period of daylight exposure: $1.9 \pm$ $1.0 \mu \mathrm{M}(\mathrm{n}=73)$ for ammonium and $0.25 \pm 0.16 \mu \mathrm{M}(\mathrm{n}=$
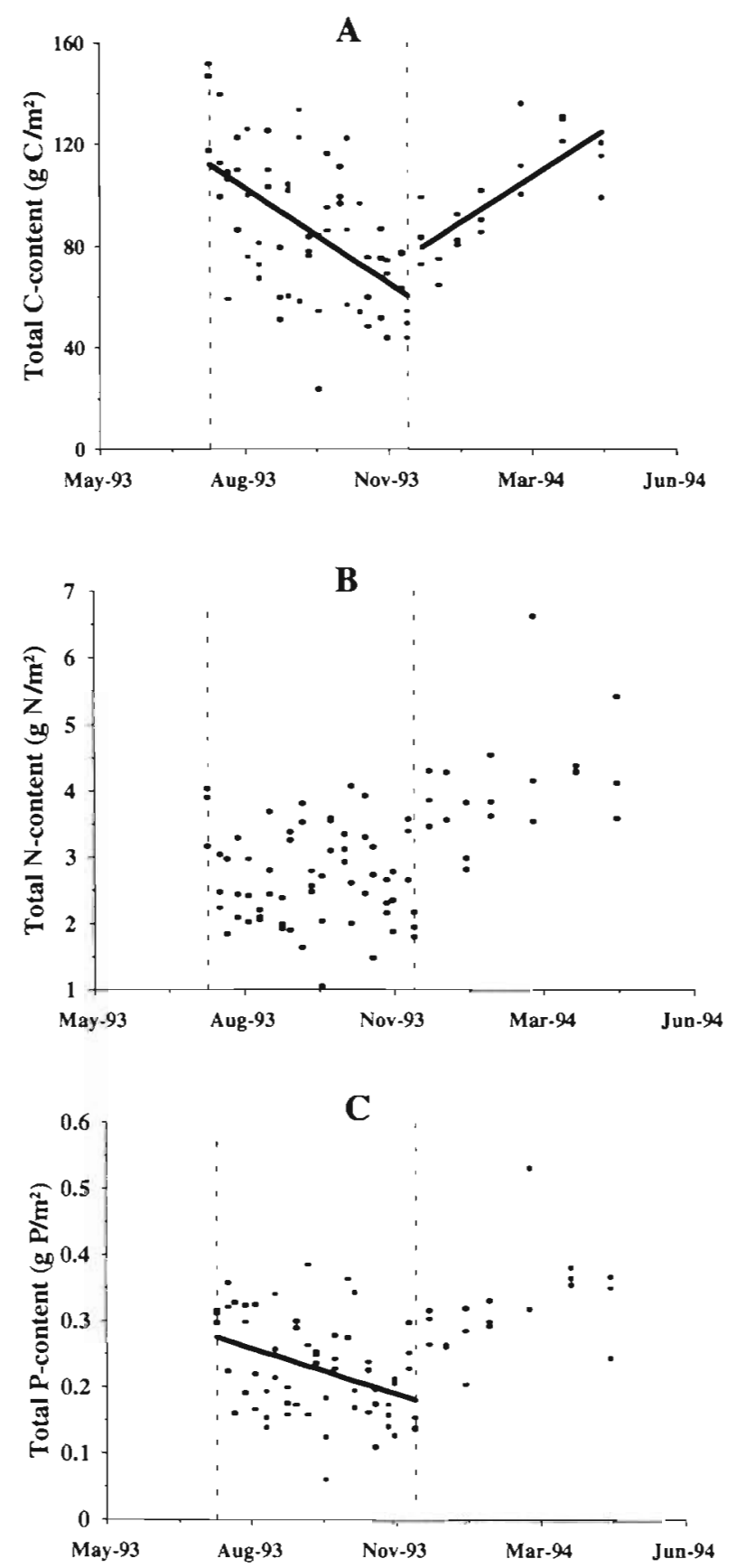

Fig. 7 Thalassia hemprachii. Changes in total nutrient contents of the combined leaf and rhizome biomasses. Solid lines and associated constants defined as in legend of Fig. 4. (A) Ccontent $\left(a=-0.377\right.$ and $b=190, \mathrm{R}^{2}=0.289, \mathrm{p}<0.01 ; c=0.360$ and $d=-47.9, \mathrm{R}^{2}=0.460, \mathrm{p}<0.01$ ); (B) N-content; and (C) Pcontent $\left(a=-0.690 \times 10^{-3}\right.$ and $\left.b=0.417, R^{2}=0.156, p<0.01\right)$ 

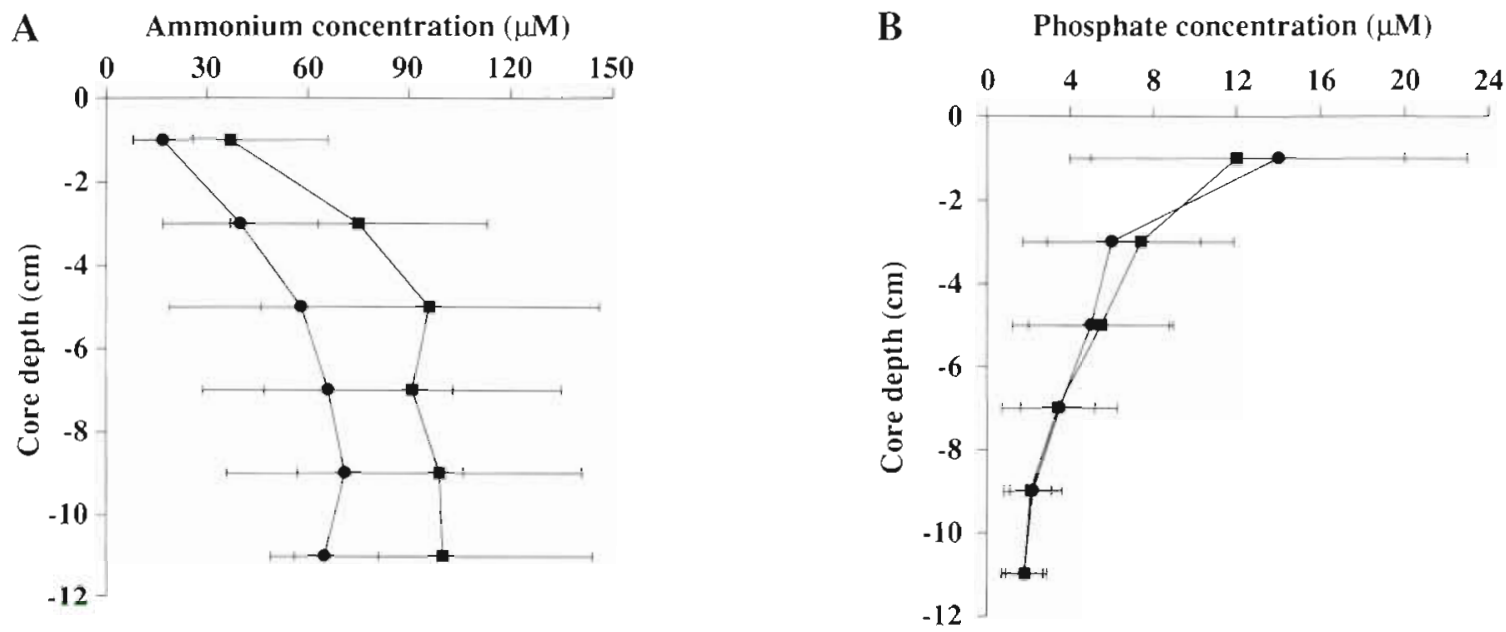

Fig. 8. Pore water (A) ammonium and (B) phosphate concentrations in the upper $12 \mathrm{~cm}$ of the sediment. Curves represent concentration profiles during periods of nocturnal $(\bullet)$ and daylight $(-)$ exposure. Symbols show the average concentrations \pm SD of the corresponding $2 \mathrm{~cm}$ sediment sections. $\mathrm{n}=17$ and 10 for ammonium and phosphate during nocturnal exposure, respectively, and $\mathrm{n}=21$ for ammonium and phosphate during daylight exposure

73) for phosphate. The ammonium pore water concentration versus sediment depth profile was consistently higher during the daylight exposure period, compared to the period May-July (ANOVA, p < 0.05; Fig. 8A). The average pore water ammonium concentration in the upper $12 \mathrm{~cm}$ of the sediment was 1.6 times higher during the daylight exposure period than during the period May-July $(p<0.05)$. There was no significant difference of the phosphate concentration in the pore water between the period of daylight exposure and the period May-July (Fig. 8B).

\section{DISCUSSION}

\section{Structural aspects}

The results of this study show that the leaf biomass of Thalassia hemprichii declined significantly in the period in which each spring low water occurred during daylight. Erftemeijer \& Herman (1994) found significant evidence that this decline was caused by daylight emergence, most probably due to the deleterious effect of severe desiccation and burning. Coinciding with the reduction of the leaf biomass, the biomass of the rhizomes also declined. While the decline in leaf biomass was due to the loss of leaves, leaf fragments and shoots (structural loss), the reduction of rhizome biomass corresponded to $30 / 12 \times \mathrm{C}$-content decline (total rhizome length remained constant). This strongly suggests that carbohydrates $\left[\left(\mathrm{CH}_{2} \mathrm{O}\right)_{x}\right]$ are mobilised. Erftemeijer \& Herman (1994) showed that the period of significant die-off of the above ground biomass of Thalassia hemprichii coincided with maximum specific leaf growth rates, which suggests that the mobilised carbohydrates are used to restore the loss of leaf biomass. Reduction in the biomass of Thalassia testudinum rhizomes in response to (repeated) harvesting of leaves has been reported previously by Dawes \& Lawrence (1979), Ogden et al. (1980) and Williams (1987). Mobilisation of carbohydrates in the rhizomes in response to leaf removal was also observed (Dawes \& Lawrence 1979, 1980, Dawes et al. 1979). The results of this study support the notion that seagrass rhizomes are storage and redistribution organs for carbohydrate reserves. Thalassia hemprichii, a species which shows extensive rhizome development, therefore, may be quite resilient to defoliation. Other similar areas in the waters around South Sulawesi that are less frequently exposed than our research location reportedly have mixed meadows with up to 8 different species (Erftemeijer 1994, Stapel et al. 1996a). The results, therefore, suggest that our reseach location is largely monospecific due to frequent seasonal daylight exposure to air, which allows only resilient species to survive.

\section{Nitrogen}

During the period of repeated loss and restoration of parts of the Thalassia hemprichii canopy, the leaf concentration of nitrogen increased. An increase in the leaf nitrogen concentration in response to defoliation has previously been reported for Thalassia testudinum by Dawes \& Lawrence (1979), Zieman et al. (1984) and Tomasko \& Dawes (1989). Young leaves of Thalassia hemprichii have a high $\mathrm{N}$-concentration compared to old leaves (Stapel \& Hemminga in press). Furthermore, 
within the leaves, nutrient concentrations are usually higher in the younger parts, i.e. near the leaf bases (Thayer et al. 1984, Zieman et al. 1984, G. Van Helden unpubl.). Thus, the observed increase in $\mathrm{N}$ may be due to proportionally more young leaf tissue. This would, however, also imply a considerable $\mathrm{P}$ increase, as this nutrient shows an even steeper decline in concentration during leaf development of Thalassia hemprichii than does N (Stapel \& Hemminga in press). Fig. 5C does not show a significant increase in the P-concentration of the leaves. This indicates that the proportionally high amount of young leaf tissue cannot be the sole explanation of the $\mathrm{N}$ - and $\mathrm{P}$-concentration profiles in leaves. Moreover, an increase in the nitrogen concentration of the rhizomes was also found, which cannot be ascribed to a decline in dry weight due to mobilisation of carbohydrates only. It is also unlikely that part of the increased nitrogen concentration in leaves and rhizomes arised from (increased) resorption from the leaves prior to abscission. Stapel \& Hemminga (in press) showed that $18 \%$ of the nitrogen can be resorbed from senescent Thalassia hemprichii leaves at Barang Lompo, but that as a result of premature loss of leaves and leaf fragments, only $56 \%$ of this capacity is realised. Due to (increased) resorption, furthermore, we would also expect an increased phosphorus concentration in the remaining tissue.

What could then be the mechanism causing the rather constant $\mathrm{N}$-content in leaves and rhizomes together, despite considerable leaf losses? It is known that prolonged leaf removal of Thalassia testudinum may cause a permanent reduction in seagrass biomass, probably as a result of nutrient depletion (Greenway 1974, Zieman et al. 1984). Leaf removal (e.g. by grazing) interrupts the recycling of leaf nutrients, because it involves export of at least part of the leaf material out of the system (Thayer et al. 1984). We found a considerable decline in both leaf and rhizome biomass over an extended period of $5 \mathrm{mo}$, but recovery occurred when the daylight exposure season ended. Furthermore, pore water nutrients were not depleted; ammonium concentrations even increased. Therefore, defoliation due to desiccation may not coincide with actual nutrient losses from the system. This would occur if a substantial amount of the detached biomass remained trapped within the meadow. This theory is supported by the study of Nienhuis et al. (1989), who hypothesised that Indo-West-Pacific seagrass beds function to a large extent as self-sustaining systems in which most of the nutrients are trapped in the large seagrass biomass and efficiently re-used within the system. Furthermore, in a coral island seagrass meadow close to the present research location, Stapel et al. (1996a) showed that only about $10 \%$ of the nitrogen incorporated in seagrass leaves for sustained production was exported. This meadow, which suffers from the same seasonal tidal exposure pattern, has a more exposed reef flat and stronger, primarily uni-directional currents than Barang Lompo, which suggests that leaf $\mathrm{N}$ export at Barang Lompo is probably less than $10 \%$ of the incorporated $\mathrm{N}$.

Alternatively, the stable $\mathrm{N}$-content in leaf and rhizome biomass may also be explained solely by a shifting balance in the various microbial processes associated with $\mathrm{N}$-cycling during the daylight exposure period. Microbial nitrogen transformations (nitrification, denitrification and $\mathrm{N}_{2}$-fixation) are largely controlled by the redox potential and the organic matter content of their (micro)environment, which can be significantly affected by plant roots (Reddy et al. 1989 . Paerl \& Pinckney 1996). Studies on seagrasses have shown a positive relation between photosynthesis and oxygen release and exudation of organic matter into the rhizosphere (Capone \& Taylor 1980, Moriarty \& Pollard 1982, Moriarty et al. 1986, O'Donohue et al. 1991, Blackburn et al. 1994). A loss in photosynthetic tissue as reported here for Thalassia hemprichii, therefore, will presumably reduce root oxygen release and organic matter exudation. This may have resulted in a shift in the balance between nitrification, denitrification and $\mathrm{N}_{2}$-fixation. A lower $\mathrm{N}$-loss due to the coupled nitrification-denitrification process and/or an increased $\mathrm{N}_{2}$-fixation may, therefore, indirectly have led to a compensation of the nitrogen losses due to leaf detachment during the period of daylight exposure.

Stapel et al. (1996b) showed that both the leaves and roots of Thalassia hemprichii at the investigated location were capable of absorbing $100 \%$ of the leaf nitrogen demand. The question of the relative share of roots and leaves in providing the total leaf nitrogen demand remained unsolved. It is very unlikely that the accumulation of nitrogen in the rhizomes during the daylight exposure period resulted from an increased nitrogen input from the leaves, as their biomass (and thus nitrogen absorption capacity) was reduced considerably. The increased nitrogen in the rhizomes may have been the result of an increased root $\mathrm{N}$-uptake allowed by the higher pore water ammonium level. The nitrogen accumulation in rhizomes during the period of daylight exposure was $4.6 \mathrm{mg} \mathrm{N} \mathrm{m} \mathrm{m}^{-2}$ (calculated from the corresponding regression line in Fig. 6E), which is 2 times more than the below-ground nitrogen demand of Thalassia hemprichii (calculated from Erftemeijer et al. 1993 and Erftemeijer \& Herman 1994). Stapel et al. (1996b) suggested that nutrient uptake by roots of Thalassia hemprichii is limited by diffusion from the pore water bulk to the root surface and thus linearly related to the pore water concentration. It is, therefore, unlikely that the 1.6 times increased pore water ammonium concentration solely 
accounted for the nitrogen built-up in rhizomes, which requires a $\mathrm{N}$-input that is 3 times larger than the below-ground demand. Therefore, the increased rhizome $\mathrm{N}$-content may also be explained by a smaller root-toleaf translocation due to a smaller $\mathrm{N}$-sink. In the period of daylight exposure, when the leaf $\mathrm{N}$-demand drops (illustrated by a lower shoot density and thus a smaller number of growth meristems; Jameson 1963, Tomlinson 1974) and the pore water ammonium concentration increases, there may thus be a build up of nitrogen in the rhizomes. This creation of a nitrogen buffer may have an important function in restoring the canopy as soon as the daylight exposure period ends.

\section{Phosphorus}

The total phosphorus content in leaves and rhizomes of Thalassia hemprichii showed a decline of $30 \%$ between 26 July and 20 December. In addition, the average pore water phosphate concentration did not significantly differ between the daylight emergence period and the recovery period, in contrast to pore water ammonium. The difference between the results of phosphorus and nitrogen seems to support the theory of nitrogen compensation due to a change in the microbial N-dynamics. Erftemeijer \& Herman (1994), who executed their research on seasonal changes in the same area, however, did find an indication for an increased pore water phosphate concentration in a period of daylight exposure. An explanation for the absence of an increased pore water level in this study perhaps may be found in the strong adsorption affinity of $\mathrm{CaCO}_{3}$ to phosphate and the heterogeneous particle size distribution of the carbonate sediment (De Kanel \& Morse 1978, Kitano et al. 1978, Erftemeijer et al. 1994). The finer the sediment, the more phosphate can be adsorbed (Erftemeijer \& Middelburg 1993, Erftemeijer et al. 1994). An increased phosphorus release coinciding with the mineralisation of elevated inputs of organic matter, therefore, could possibly have been masked due to a larger fraction of fine sediment particles, relative to the study of Erftemeijer \& Herman (1994), adsorbing more phosphate.

\section{Recovery}

The parameters that changed during daylight exposure did not always return to their initial values. Also, parameters that did not significantly change during the daylight exposure period under investigation showed a change in the recovery period. This can be ascribed to year-to-year variations in environmental and climatic conditions (cf. Walker \& McComb 1988, Hillman et al. 1989, Erftemeijer \& Herman 1994). On the other hand, an increasing rhizome length in the recovery period (Fig. 4E) may be required for the recruitment of new shoots (Fig. 4B; cf. Duarte \& Sand-Jensen $1990 \mathrm{a}$, b). Furthermore, the fast re-establishment of the seagrass canopy in the early phase of the recovery period (Fig. 4A, C) almost instantly enlarges the capacity of nutrient uptake from the water column and reduces the need for rhizome-to-leaf nutrient translocation. This may explain the enduring high rhizome $\mathrm{N}$-content after 20 December (at least until $25 \mathrm{April}$; Fig. 6E) and the rather instantaneous transition of the summed $\mathrm{N}$ - and P-contents of leaves and rhizomes between the daylight exposure and the recovery period

\section{Conclusion}

During the period of frequent daylight exposure of the seagrass bed at the reef flat of Barang Lompo, the leaf and rhizome biomass and shoot density of Thalassia hemprichii declined considerably and there was a clear redistribution of $\mathrm{C}, \mathrm{N}$ and $\mathrm{P}$. Despite biomass reduction, the total amount of nitrogen fixed in seagrass biomass remained unchanged: the quantity of nitrogen that was lost due to detachment of leaf biomass was counterbalanced by increased tissue nitrogen concentrations, especially in the rhizomes. Enhanced ammonium uptake by roots most probably played an important role in compensating the nitrogen losses. Two theories have been discussed explaining the stability of the total leaf and rhizome nitrogen content. The first theory describes the Thalassia hemprichii seagrass bed at Barang Lompo as a relatively closed system with respect to nitrogen and presumably phosphorus as well, implying efficient recycling of nutrients within the meadow. The second theory postulates that the loss of part of the photosynthesising canopy due to daylight exposure has a series of consequences for microbial N-transformation processes in the sediment, which indirectly affects the plants' nitrogen status. This study shows that Thalassia hemprichii, covering the reef flat of an intertidal tropical off-shore coral island, which is often considered as a nutrient-poor environment, is rather resilient to a significant canopy die-off and concomitant nutrient losses.

Acknowledgements. Drs P. H. Nienhuls, J. J. Middelburg and M. A. Mateo and J van der Nat are acknowledged for their critical comments on earlier drafts of this manuscript. Field and laboratory assistance was kindly provided by B. Philipsen and R. Nijboer. J. Nieuwenhuize and Y Maas are especially acknowledged for their efforts in the analysis of $\mathrm{C}-, \mathrm{N}$ - and $\mathrm{P}$ - 
contents. Dr P. M. J. Herman provided statistical advice. This study was funded by the Netherlands Foundation for the Advancement of Tropical Research (WOTRO; grant W86108). Communication no. 2230 of the Netherlands Institute of Ecology, Centre for Estuarine and Coastal Ecology, Yerseke, The Netherlands

\section{LITERATURE CITED}

Alcoverro T, Duarte CM, Romero J (1995) Annual growth dynamics of Posidonia oceanica: contribution of largescale versus local factors to seasonality. Mar Ecol Prog Ser 120:203-210

Allen SE (1974) Chemical analysıs of ecological materials. Blackwell, Oxford

Baldwin JR, Lovvorn JR (1994) Expansion of seagrass habitat by exotic Zostera japonica, and its use by dabbling ducks and brant in Boundary Bay, British Columbia. Mar Ecol Prog Ser 103:119-127

Blackburn TH, Nedwell DB, Wiebe WJ (1994) Active mineral cycling in a Jamaican seagrass sediment. Mar Ecol Prog Ser 110:233-239

Brouns JJWM, Heijs IML (1986) Structural and functional aspects of seagrass communities and associated algea from the tropical West-Pacific. PhD, thesis Catholic Uni. versity, Nijmegen

Bulthuis DA, Woelkering WMJ (1983) Seasonal variation in standing crop, density and leaf growth rate of the scagrass, Heterozostera tasmanica, in Western Port and Port Philips Bay, Victoria, Australia. Aquat Bot 16:111-136

Capone DG, Taylor BF (1980) $\mathrm{N}_{2}$-fixation in the rhizosphere of Thalassia testudinum. Can J Microbiol 26:998-1005

Dawes CJ, Bird K, Durako M, Goddard R, Hoffman W, Mclntosh R (1979) Chemical fluctuation due to seasonal and cropping effects on an algal-seagrass community. Aquat Bot 6:79-86

Dawes CJ, Lawrence JM (1979) Effects of blade removal un the proximate composition of the rhizome of the seagrass Thalassia testudinum Banks ex Konig. Aquat Bot 7 255-266

Dawes CJ. Lawrence JM (1980) Seasonal changes in the proximate constituents of the seagrasses Thalassia testudinum, Halodule wrightii, and Syringodium filiforme. Aquat Bot 8:371-380

De longh $\mathrm{HH}$, Wenno BJ, Meelis E (1995) Seagrass distribution and seasonal biomass changes in relation to dugong grazing in the Moluccas, East Indonesia. Aquat Bot 50: $1-19$

De Kanel J, Morse JW (1978) The chemistry of orthophosphate uptake from seawater on to calcite and aragonite. Geochim Cosmochim Acta 42:1335-1340

De Klerk LG (1982) Sea levels, reefs and coastal plains of southwest Sulawesi, Indonesia; a morphogenetic-pedological study. PhD thesıs, State University of Utrecht (in Dutch)

Den Hartog C (1970) The seagrasses of the world. North Holland Publ, Amsterdam

Duarte CM (1989) Temporal biomass variability and production biomass relationships of seagrass communities. Mar Ecol Prog Ser 51:269-276

Duarte CM, Sand-Jensen K (1990a) Seagrass colonisation: patch furmation and patch growth in Cymodocea nodosa Mar Ecol Prog Ser 65:193-200

Duarte CM, Sand-Jensen K (1990b) Seagrass colonisation biomass development and shoot demography in Cymodocea nodosa patches. Mar Ecol Prog Ser 67:97-103
Erftemeijer PLA (1994) Differences in nutrient concentrations and resources between seagrass communities on carbonate and terrigenous sediments in South Sulawesi, Indonesia. Bull Mar Sci 54:403-419

Erftemeijer PLA, Herman PMJ (1994) Seasonal changes in environmental variables, biomass, production and nutrient contents in two contrasting tropical intertidal seagrass beds in South Sulawesi, Indonesla. Oecologia 99:45-59

Erftemeljer PLA, Middelburg JJ (1993) Sediment-nutrient interactions in tropical seagrass beds: a comparison between a terngenous and a carbonate sedimentary environment in South Sulawesi (Indonesia). Mar Ecol Prog Ser 102:187-198

Erftemeijer PLA, Osinga R, Mars AE (1993) Primary production of seagrass beds in South Sulawesi (Indonesia). Aquat Bot 46:67-70

Erftemeijer PLA, Stapel J, Drossaert WME, Smekens MJE (1994) The limited effect of in situ phosphorus and nitrogen additions to seagrass beds on carbonate and terrigenous sediments in South Sulawesi, Indonesia. J Exp Mar Biol Ecol 182:123-140

Greenway $M$ (1974) The effects of cropping on the growth of Thalassia testudinum (Konig) in Jamaica. Aquaculture 4: $199-206$

Hillman K, Walker DI, Larkum ADW, McComb AJ (1989) Productivity and nutrient limitatıon. In: Larkum ADW. McComb AJ, Shepherd SA (eds) Biology of seagrasses. A treatise on the biology of seagrasses with special reference to the Australian region. Aquatic plant studies 2 . Elseviter. Amsterdam, p 635-685

Jameson DA (1963) Responses of individual plants to harvesting. Bot Rev 29:532-594

Kelderman P (1985) Nutrient dynamics in the sediment of lake Frevelungen (SW Netherlands). PhD thesis, State Unıversity of Groningen

Kitano Y, Okumura M. Idogaki M (1978) Uptake of phosphate ions by calcium carbonate. Geochem J 12:29-37

Moriarty DJW, lverson R, Pollard PC (1986) Exudation of organic carbon by seagrass Halodule wrightii and its effect on bacterial growth in the sediment. J Exp Mar Biol Ecol 96:115-126

Moriarty DJW, Pollard PC (1982) Diel variation of bacterial productivity in seagrass (Zostera capricorni) beds measured by rate of thymidine incorporation into DNA. Mar Biol 72:165-173

Nienhuls PH, Coosen J, Kiswara W (1989) Community structure and bromass distribution of seagrasses and macrofauna in the Flores Sed, Indonesia. Neth J Sea Res 23: $197-214$

Nieuwenhuize J, Poley-Vos CH, Van den Akker AH, Van Delft W (1991) Comparison of microwave and conventional extraction techniques for the determination of metals in solls, sediment and sludge samples by atomic spectrometry. Analyst 116:347-351

O'Donohue MJ, Moriarty DJW, Mac Rae IC (1991) Nitrogen fixation in sediments and the rhizosphere of the seagrass Zostera capricorni. Microb Ecol 22:53-64

Ogden JC, Tighe S, Miller S (1980) Grazing of seagrasses by large herbivores in the Carribean. Am Zool 20:949 (abstract)

Paerl HW, Pinckney JL (1996) A mini-review of microbial consortia: their roles in aquatic production and biochemical cycling. Microb Ecol 31:225-247

Pérez M Romero J (1992) Photosynthetic response to light and temperature of the seagrass Cymodocea nodosa and the prediction of its seasonality. Aquat Bot 43:51-62

Philippart CJM (1995) Effects of shading on growth, biomass 
and population maintenance of the intertidal seagrass Zostera noltii Hornem. in the Dutch Wadden Sea. J Exp Mar Biol Ecol 188:199-213

Reddy KR, Patrick WH, Lindau CW (1989) Nitrification-denitrification at the plant root-sediment interface in wetlands. Limnol Oceanogr 6:1004-1013

Stapel J, Aarts TL, Van Duynhoven BHM, De Groot JD, Van den Hoogen PHW, Hemminga MA (1996b) Nutrient uptake by leaves and roots of the seagrass Thalassia hemprichii in the Spermonde Archipelago, Indonesia. Mar Ecol Prog Ser 134:195-206

Stapel J, Hemminga MA (in press) Nutrient resorption from seagrass leaves. Mar Biol

Stapel J, Nijboer R, Philipsen B (1996a) Initial estimates of the export of leaf litter from a seagrass bed in the Spermonde Archipelago, South Sulawesi, Indonesia. In: Kuo Ji Philips RC, Walker DI, Kirkman H (eds) Seagrass biology: proceedings of an international workshop. Faculty of Sciences, UWA, Nedlands, Western Australia, p 155-162

Strickland JDH, Parsons TR (1972) A practical handbook of seawater analysis. Bull Fish Res Bd Can 167:1-311

Thayer GW, Bjorndal KA, Ogden JC, Williams SL, Zieman JC

This article was submitted to the editor
(1984) Role of larger herbivores in seagrass communities. Estuaries 7:351-376

Tomasko DA, Dawes CJ (1989) Effects of partial defoliation on remaining intact leaves in the seagrass Thalassia testudinum Banks ex Konig. Bot Mar 32:235-240

Tomasko DA, Dawes CJ (1990) Influences of season and water depth on the clonal biology of the seagrass Thalassia lestudinum. Mar Biol 105:345-351

Tomlinson PB (1974) Vegetative morphology and meristem dependence - the foundation of productivity in seagrass. Aquaculture 4:107-130

Walker DI, McComb AJ (1988) Seasonal variation in the production, biomass and nutrient status of Amphibolis antarctica (Labill.) Sonder ex Aschers. and Posidonia australis Hook.f. in Shark Bay. Western Australia. Aquat Bot 31. $259-275$

Williams SL (1987) Competition between the seagrasses Thalassia testudinum and Syringodium filiforme in a Caribbean lagoon. Mar Ecol Prog Ser 35:91-98

Zieman JC, Iverson RL, Ogden JC (1984) Herbivory effects on Thalassia testudinum leaf growth and nitrogen content. Mar Ecol Prog Ser 15:151-158

Manuscript first received: September 23, 1996 Revised version accepted: December 30, 1996 